\title{
PENGARUH LINGKUNGAN KERJA TERHADAP PRODUKTIVITAS KERJA PEGAWAI PADA DINAS KETAHANAN PANGAN KABUPATEN LAMPUNG BARAT
}

\author{
Erna Utami ${ }^{(1)}$, Trisnowati Josiah ${ }^{(2)}$, Sodirin ${ }^{(3)}$ \\ Fakultas Ekonomi Universitas Sang Bumi Ruwa Jurai \\ erna_utami@gmail.com,trisnowati.josiah@fe.saburai.ac.id,sodirin@fe.saburai.ac.id
}

\begin{abstract}
Abstrak. Lingkungan kerja adalah segala sesuatu yang ada disekitar para pekerja dan yang dapat mempengaruhi dirinya dalam menjalankan tugas-tugas yang dibebankannya. Masalah yang dihadapi adalah kondisi lingkungan kerja yang belum mendukung di Dinas Ketahanan Pangan Kabupaten Lampung Barat dan produktivitas kerja pegawai yang masih belum optimal. Tujuaan penelitian ini adalah untuk mengetahui pengaruh Lingkungan Kerja Terhadap Produktivitas kerja pegawai pada Dinas Ketahanan Pangan Kabupaten Lampung Barat. Pengumpulan data penelitian menggunakan teknik populasi penelitian dari 33 responden. Metode penelitian yang digunakan adalah analisis kuantitatif yaitu regresi linier sederhana. Berdasarkan hasil analisis diperoleh persamaan bahwa $\mathrm{Y}=6.967+0.675(\mathrm{X})$. Hasil pengujian menggunakan rumus $t$ student, menunjukkan bahwa $t_{\text {hitung }} 3,251>t_{\text {tabel }} 2,068$, berarti Ho ditolak dan Ha diterima, dengan demikian hipotesis yang diajukan dalam penelitian ini "Lingkungan Kerja berpengaruh positif terhadap Produktivitas Kerja Pegawai pada Dinas Ketahanan Pangan Kabupaten Lampung Barat" dapat diterima.
\end{abstract}

Kata kunci: Aktivitas, Kinerja, Pegawai, Produktif.

\section{PENDAHULUAN}

Keberhasilan dan kegagalan pembangunan tidak lepas dari peran yang dimainkan aparatur pemerintahan sebagai abdi negara dan abdi masyarakat. Peranan tersebut diwujudkan dalam bentuk kepemimpinan dalam organisasi yang menjadi penggerak bawahan dan menjadi satu kesatuan pola manajemen pemerintahan dan manajemen pembangunan di daerah.

Dalam rangka mencapai tujuan tersebut, Dinas Ketahanan Pangan Kabupaten Lampung Barat, berperan secara aktif untuk mengoordinasikan, mensinkronkan dan mendorong seluruh pemangku kepentingan baik secara horizontal maupun vertikal dalam mewujudkan ketahanan pangan sampai tingkat perseorangan dengan berlandaskan kedaulatan pangan dan kemandirian pangan secara berkesinambungan. Perwujudan ketahanan pangan tersebut ditandai dengan tiga hal pokok yang harus diperhatikan, yaitu: (i) ketersediaan pangan yang berbasis pada pemanfaatan sumber daya lokal secara optimal; (ii) keterjangkauan pangan dari aspek fisik dan ekonomi oleh seluruh masyarakat, dan (iii) pemanfaatan pangan atau konsumsi pangan dan gizi

Salah satu faktor yang mempengaruhi produktivitas kerja pegawai adalah lingkungan kerja. Dimana dalam lingkungan kerja, setiap pegawai memiliki suatu harapan usaha dan kinerja. Meskipun lingkungan kerja merupakan faktor yang sangat penting dan mempunyai pengaruh yang sangat besar terhadap kinerja pegawai, tapi masih banyak satuan kerja yang masih kurang memperhatikan kondisi lingkungan kerja nya. Kondisi lingkungan kerja yang baik, sehat, nyaman, dan menyenangkan yang akan membuat pegawai merasa betah berada di ruang kerja dan lebih bersemangat dalam menyelesaikan tugasnya.

Lingkungan kerja yang diharapkan adalah yang aman, tentram, bersih, tidak bising, terang dan bebas dari segala macam 
ancaman maupun gangguan yang menghambat kerja pegawai. Secara fisik lingkungan dapat berupa lokasi tempat kerja, kondisi bangunan dan fasilitas kerja, sedangkan lingkungan non-fisik/psikologis meliputi keberadaannya sangat ditentukan oleh tindakan organisasi melalui cara-cara pengoperasian, yaitu proses penghimpunan Sumber Daya Manusia, modal dan peralatan dengan cara yang paling efisien untuk mencapai tujuan.

Pegawai sebagai sumber utama penggerak kegiatan organisasi harus dapat diberdayakan secara maksimal agar dapat berperan dalam kapasitasnya sebagai abdi negara yang harus melaksanakan tugastugas pemerintahan, pembangunan dan memberikan pelayanan kepada masyarakat luas. Indikator pengukuran keberhasilan dalam melaksanakan tugasnya adalah pencapaian target pekerjaan sesuai dengan rencana yang telah ditetapkan. Sebagai indikator pengukur tingkat kepuasan kerja tersebut harus didukung oleh suasana lingkungan kerja yang kondusif dan motivasi yang tinggi dari setiap diri pegawai di Dinas Ketahanan Pangan Kabupaten Lampung Barat.

Produktivitas kerja menurut Mangkunegara (2003) adalah sebagai hasil kerja secara kualitas dan kuantitas yang dapat dicapai oleh seorang karyawan/pegawai dalam melaksanakan tugas sesuai dengan tanggung jawab yang diberikan kepadanya. Pegawai di Dinas Ketahanan Pangan Kabupaten Lampung Barat sudah cukup memadai baik dari segi kuantitas maupun kualitasnya. Spesifikasi keahlian dan tingkat profesionalismenya meski sudah cukup tetapi masih perlu peningkatan, khususnya dalam memberikan dan meningkatnya keanekaragaman konsumsi pangan masyaraka untuk mewujudkan pemantapan ketahanan pangan yang tercermin dari tertanganinya desa rawan pangan, stabilnya harga dan pasokan pangan pokok.
Dengan kualitas kinerja pegawai yang semakin meningkat diharapkan adanya perubahan kerja. Kinerja pegawai yang meningkat akan menimbulkan rasa memiliki organisasi dan akan tercipta rasa kepuasan, baik pada individu maupun organisasi secara keseluruhan. Elemen yang digunakan dalam analisa ini adalah kondisi pegawai menurut jenjang pendidikan formal dan keadaan pegawai berdasarkan jenjang pendidikan karier.

Berdasarkan faktor dan uraian di atas, maka penulis tertarik untuk menelitinya lebih lanjut dengan judul: "Pengaruh Lingkungan Kerja terhadap Produktivitas Kerja Pegawai pada Dinas Ketahanan Pangan Kabupaten Lampung Barat".

\section{KAJIAN TEORI}

\section{Definisi Lingkungan Kerja}

Lingkungan kerja adalah hal-hal yang berhubungan atau ada dalam lingkungan pekerjaannya dan dapat mempengaruhi dirinya dalam menjalankan tugas yang diberikan, baik itu yang berhubungan dengan kebendaan atau fisik maupun yang berhubungan dengan manusia. Lingkungan kerja yang diharapkan adalah yang aman, tentram, bersih, tidak bising, terang dan bebas dari segala macam ancaman maupun gangguan yang menghambat kerja pegawai. Secara fisik lingkungan dapat berupa lokasi tempat kerja, kondisi bangunan dan fasilitas kerja, sedangkan lingkungan nonfisik/psikologis meliputi keberadaannya sangat ditentukan oleh tindakan organisasi melalui cara-cara pengoperasian, yaitu proses penghimpunan Sumber Daya Manusia, modal dan peralatan dengan cara yang paling efisien untuk mencapai tujuan.

Lokasi tempat kerja juga berpengaruh pada pekerjaannya. Lokasi kerja yang mudah dijangkau oleh kendaraan umum lebih membantu pekerja daripada lokasi 
yang sukar dijangkau oleh kendaraan umum. Fasilitas kerja sangat diperlukan untuk terlaksananya pekerjaan dengan lancar dan tepat waktu. Makin lengkap fasilitas kerja yang disediakan oleh lembaga makin meningkatkan produktivitas lembaga tersebut. Tersedianya tata tertib yang harus ditaati oleh semua pekerja, merupakan suatu kebutuhan. Dengan tata tertib semua karyawan dapat menempatkan diri dalam pelaksanaan tugasnya dan termotivasi untuk bekerja lebih baik.

\section{Produktivitas Kerja}

Produktivitas kerja memegang peranan yang sangat penting. Karena maju mundurnya organisasi sangatlah tergantung pada naik turunnya produktivitas kerja pegawai. Seorang pegawai yang melakukan suatu jenis pekerjaan tertentu dapat dipastikan akan memperoleh hasil. Hasil adalah output akan produksi dari suatu aktivitas kerja. Produksi dan produktivitas adalah dua hal yang mempunyai hubungan yang erat dan merupakan masalah yang pokok dalam perusahaan/dinas.

Berkaitan dengan produktivitas tersebut, (Sinungan, 2013) menyatakan bahwa : "Produktivitas adalah sebagai perbandingan antara totalitas pengeluaran dengan waktu tertentu dibagi totalitas masukan selama periode tertentu, lebih lanjut dikatakan bahwa produktivitas keluaran tiap jam kerja dengan memperhatikan produktivitas kerja yang dihasilkan". Selanjutnya, Kussriyanto (2010) menyatakan "Produktivitas dapat juga diartikan sebagai suatu sikap mental yang selalu mempunyai pandangan bahwa mutu kehidupan hari ini harus lebih baik dari pada hari kemarin dan hari esok lebih baik dari hari ini".

Produktivitas ditunjukkan oleh perilakunya sebagai keluaran (output) dari suatu proses berbagai komponen kejiwaan yang melatarbelakanginya, bahwa motivasi kerja sering diwujudkan oleh produktivitas setiap individu yang terlibat didalamnya. Sebagai manusia, tenaga kerja mempunyai watak, temperamen serta karakter yang berbeda-beda, sehingga memberikan reaksi terhadap permasalahan dan lingkungan kerja mereka, hal ini merupakan masalah yang rumit dan paling untuk diperkirakan karena sebagai tenaga kerja mereka mempunyai latar belakang dengan bermacam-macam perbedaan seperti tingkat pendidikan, pengalaman, budaya, nilai dan tujuan hidup yang akan memberikan suasana kehidupan kerja yang beragam.

\section{Pengukuran Produktivitas Kerja}

Pengukuran produktivitas tenaga kerja menurut sistem pemasukan fisik perorangan/perorang atau per jam kerja orang diterima secara luas, namun dari sudut pandangan/pengawasan harian, pengukuran-pengukuran tersebut pada umumnya tidak memuaskan, dikarenakan adanya variasi dalam jumlah yang diperlukan untuk memproduksi satu unit produk yang berbeda. Oleh karena itu, digunakan metode pengukuran waktu tenaga kerja (jam, hari atau tahun). Pengeluaran diubah ke dalam unit-unit pekerja yang biasanya diartikan sebagai jumlah kerja yang dapat dilakukan dalam satu jam oleh pekerja yang terpercaya yang bekerja menurut pelaksanaan standar. Karena hasil maupun masukan dapat dinyatakan dalam waktu, produktivitas tenaga kerja dapat dinyatakan sebagai suatu indeks yang sangat sederhana = Hasil dalam jam-jam yang standar : Masukan dalam jam-jam waktu.

Untuk mengukur suatu produktivitas perusahaan dapatlah digunakan dua jenis ukuran jam kerja manusia, yakni jam-jam kerja yang harus dibayar dan jam-jam kerja yang dipergunakan untuk bekerja. Jam kerja yang harus dibayar meliputi semua jam-jam kerja yang harus dibayar, ditambah 
jam-jam yang tidak digunakan untuk bekerja namun harus dibayar, liburan, cuti, libur karena sakit, tugas luar dan sisa lainnya. Sinungan (2013) mengemukakan bahwa bagi keperluan pengukuran umum produktivitas tenaga kerja kita memiliki unit-unit yang diperlukan, yakni: kuantitas hasil dan kuantitas penggunaan masukan tenaga kerja.

\section{Faktor-faktor yang Mempengaruhi Produktivitas Kerja}

Menurut Ravianto (2012), produktivitas kerja seorang pegawai dipengaruhi oleh beberapa faktor sebagai berikut :

a. Pendidikan dan pelatihan

b. Disiplin

c. Sikap dan etika kerja

d. Motivasi kerja

e. Gizi dan kesehatan

f. Jaminan sosial

g. Lingkungan dan iklim kerja

h. Teknologi

\section{METODE PENELITIAN}

\section{Objek Penelitian}

Objek penelitian ini adalah pegawai yang ada di Dinas Ketahanan Pangan Kabupaten Lampung Barat, yang beralamat di Jln.Mawar No.3 Komplek Pemda Liwa Lampung Barat. Penelitian ini di laksanakan dari bulan April sampai dengan Juli 2018.

\section{Metode dan Teknik Pengumpulan Data}

Dalam penelitian ini jenis data yang diperlakukan adalah :

a. Data Primer

Data primer merupakan data dasar yang akan diperoleh langsung tanpa perantara orang atau lembaga lain sebagai pihak ketiga. Data primer ini diperoleh dengan wawancara melalui responden dengan menggunakan daftar pertanyaan.

\section{b. Data Sekunder}

Data skunder merupakan data yang diperoleh melalui orang lain yang berhubungan dengan permasalahan yang dipecahkan. Data sekunder ini diperoleh melalui cara studi dokumenter yaitu mengumpulkan dan mempelajari brosurbrosur serta dokumen organisasi.

\section{Sampel dan Populasi}

Sampel penelitian adaalah sebagian dari populasi yang mewakili sifat dan karakter yang sama. Dengan mengambil sampel dimaksudkan untuk menyederhanakan jumlah subjek yang harus diteliti, tetapi hasil penelitian terhadap sampel itu akan digeneralisasikan pada populasi yang ada. Untuk menentukan banyak sampel, peneliti menggunakan pedoman dari pendapat Arikunto (2010), apabila subyeknya kurang dari 100, lebih baik diambil semua sehingga penelitiannya merupakan penelitian populasi. Selanjutnya jika jumlah subyeknya besar, dapat diambil $10 \%-15 \%$ atau $20 \%-25 \%$ atau lebih. Dalam penelitian ini merupakan penelitian sampel. Adapun jumlah sampel yang diambil adalah seluruh populasi pegawai yang ada di Dinas Ketahanan Pangan Kabupaten Lampung Barat sebanyak 33 orang.

\section{Metode Analisis Data}

Untuk pengolahan data dalam bentuk tabulasi hasil jawaban responden kemudian dilakukan analisis data melalui metode analisis secara kualitatif dan analisa kuantitatif. Analisis kualitatif dilakukan dengan analisis tabel tunggal atau secara parsial yang akan menggambarkan kriteria masing-masing variabel. Analisis kuantitatif yang dilakukan berdasarkan data 
primer yang diperoleh dari penyebaran instrument (daftar pertanyaan) kepada sampel, dan untuk mengetahui pengaruh dari variabel bebas (independent variable) terhadap variabel terikat (dependent variable).

Persamaan Regresi Linear Sederhana menentukan persamaan regresi linear sederhana untuk X :

$$
Y=a+b X+e
$$

Keterangan:

$$
\begin{aligned}
& \mathrm{Y}=\text { Produktivitas kerja } \\
& \mathrm{a}=\text { Konstanta } \\
& \mathrm{b}=\text { Koefisien regresi } \mathrm{X} \\
& \mathrm{X}=\text { Lingkungan kerja } \\
& \mathrm{e}=\text { Faktor kesalahan }
\end{aligned}
$$

Untuk mengetahui besarnya pengaruh, penghitungan koefisien korelasi tersebut kemudian dilanjutkan dengan Rumus Koefisien Determinasi atau Koefisien Penentu (KP):

$$
K P=(r)^{2} x 100 \%
$$

Untuk menguji secara hipotesis secara parsial digunakan Uji t dengan rumus :

$$
t_{\text {hitung }}=\frac{r \sqrt{N-2}}{\sqrt{1-r^{2}}}
$$

Keterangan:

$$
\begin{array}{ll}
\mathrm{t}_{\text {hitung }} & =\text { Nilai } \mathrm{t} \\
\mathrm{r} & =\text { Koefisien Korelasi } \\
\mathrm{N} & =\text { Jumlah responden } \\
& \quad \text { (Sugiyono, 2008). }
\end{array}
$$

Kriteria untuk Uji $\mathrm{t}$ adalah sebagai berikut :

a) Jika $t_{\text {hitung }}>t_{\text {tabel }}$ maka Ha diterima dan Ho ditolak.

b) Jika $t_{\text {hitung }} \leq \mathrm{t}$ tabel maka Ha ditolak dan Ho diterima.
Taraf signifikan dalam penelitian ini digunakan $\alpha=0,05$ atau 5\%. Yang dimaksud dengan Hipotesis nol (Ho) dan Hipotesis alternatif (Ha) adalah :

Ho $=r \leq 0=$ Berarti tidak ada pengaruh lingkungan kerja terhadap produktivitas kerja

$\mathrm{Ha}=\mathrm{r}>0=$ Berarti ada pengaruh lingkungan kerja terhadap produktivitas kerja.

\section{HASIL DAN PEMBAHASAN}

Hasil uji validitas yang dilakukan untuk menunjukkan bahwa koefisien korelasi pearson moment untuk setiap item butir pertanyaan dengan skor total variabel lingkungan kerja (X), dan produktifitas kerja (Y) signifikan pada tingkat signifikan $\alpha 0,05$. Secara ringkas uji validitas variabel dapat dilihat pada Tabel 1 dan Tabel 2.

Tabel 1. Hasil Uji Validitas Instrumen Variabel Lingkungan kerja

\begin{tabular}{lccc} 
Indikator & r hitung & r tabel & Keterangan \\
\hline X11 & 0.953 & 0.514 & Valid \\
X12 & 0.871 & 0.514 & Valid \\
X13 & 0.953 & 0.514 & Valid \\
X14 & 0.871 & 0.514 & Valid \\
X15 & 0.885 & 0.514 & Valid \\
\hline
\end{tabular}

Nilai $r$ hitung lingkungan kerja lebih besar dari $r$ tabel (0.514), sehingga seluruh indikator dinyatakan valid.

Tabel 2. Hasil Uji Validitas Instrumen Variabel Produktifitas kerja

\begin{tabular}{lccc}
\hline \multicolumn{1}{c}{ Indikator } & r hitung & r tabel & Keterangan \\
\hline Y11 & 0.881 & 0.514 & Valid \\
Y12 & 0.942 & 0.514 & Valid \\
Y13 & 0.942 & 0.514 & Valid \\
Y14 & 0.824 & 0.514 & Valid \\
Y15 & 0.824 & 0.514 & Valid \\
\hline
\end{tabular}


Tabel 2. Menunjukkan hasil perhitungan seluruh indikator untuk variabel produktifitas kerja adalah lebih besar dari $r$ tabel, sehingga seluruh indikator dinyatakan valid.

\section{Uji Reliabilitas Data}

Nilai reliabilitas konsistensi internal menunjukkan bahwa koefisien Alpha Cronbach dinyatakan reliabel karena lebih besar dari 0,60. Dengan demikian item pengukuran pada masing-masing indikator dalam variabel-variabel penelitian dinyatakan reliabel dan selanjutnya dapat digunakan dalam penelitan.

\section{Analisis Kuantitatif}

Berdasarkan tabel diatas dapat dilihat persamaan regresi linier sederhana adalah $\mathrm{Y}$ $=6,967+0,675(\mathrm{X})$. Nilai konstanta yang diperoleh sebesar 6,967, hal ini berarti bahwa jika variabel independen (lingkungan kerja) adalah bernilai nol, maka besarnya produktifitas kerja yang terjadi adalah 6,967. Nilai koefisien regresi variabel lingkungan kerja (X) sebesar 0,675, hal ini menunjukkan bahwa setiap kenaikan satu satuan lingkungan kerja akan mengakibatkan kenaikan produktifitas kerja sebesar 0,675.

Koefisien Determinasi dengan rumus $\mathrm{KD}=\mathrm{R}^{2} \times 100 \%$, hasil pengujian menunjukkan bahwa nilai $R$ square sebesar 0.325 . Nilai $R$ square ini menunjukkan bahwa besarnya kontribusi variabel independen terhadap variabel dependen adalah sebesar $32,5 \%$, sedangkan sisanya sebesar $67,5 \%$ ditentukan oleh variabel lain yang tidak teridentifikasi dalam penelitian ini.

Pengujian hipotesis dilakukan untuk menjawab model kelayakan hipotesis penelitian. Pengujian dilakukan dengan menggunakan uji $\mathrm{t}$ pada tingkat kepercayaan 95\% atau $\alpha$ sebesar 0.05 dari hasil output SPSS yang diperoleh, apabila $t_{\text {hitung }}>t_{\text {tabel. }}$. Maka model dinyatakan layak digunakan dalam penelitian ini dan sebaliknya apabila $t_{\text {hitung }}<t_{\text {tabel, }}$ maka model dikatakan tidak layak, atau dengan signifikan (Sig) < 0.05 maka model dinyatakan layak digunakan dalam penelitian ini dan sebaliknya apabila signifikan (Sig) > 0.05 maka model dinyatakan tidak layak digunakan.

Pengujian yang diperoleh dapat menjawab hipotesis yang menyatakan "Lingkungan kerja berpengaruh terhadap produktifitas kerja." Pengujian dilakukan dengan menggunakan uji $t$ yang menunjukkan bahwa lingkungan kerja berpengaruh terhadap produktifitas kerja. Pengujian dilakukan dengan menggunakan uji t pada tingkat keyakinan signifikansi $\alpha$ 0.05. Dari hasil dapat diketahui bahwa tingkat signifikansi sebesar 0,004 $<0,05$ dengan nilai $t_{\text {hitung }}>t_{\text {tabel }}$ yaitu $3,251>$ 2,068. Dengan demikian hipotesis diterima yang berarti lingkungan kerja berpengaruh terhadap produktifitas kerja.

\section{KESIMPULAN DAN SARAN}

\section{Kesimpulan}

Berdasarkan hasil penelitian dapat disimpulkan bahwa pengujian hipotesis yang menyatakan Lingkungan kerja berpengaruh terhadap produktifitas kerja pada Dinas Ketahanan Pangan Kabupaten Lampung Barat, Pengujian dilakukan dengan menggunakan uji t. Nilai $R$ square sebesar 0.325. Nilai $R$ square ini menunjukkan bahwa besarnya kontribusi variabel independen terhadap variabel dependen adalah sebesar 32,5\%, sedangkan sisanya sebesar $67,5 \%$ ditentukan oleh variabel lain yang tidak teridentifikasi dalam penelitian ini. Dari hasil dapat diketahui bahwa tingkat signifikansi sebesar $0,004<0,05$ dengan nilai thitung > $\mathrm{t}_{\text {tabel }}$ yaitu 3,251>2,068, dengan demikian 
hipotesis diterima yang berarti lingkungan kerja berpengaruh terhadap produktifitas kerja pada Dinas Ketahanan Pangan Kabupaten Lampung Barat.

\section{Saran}

Adapun saran yang diajukan peneliti adalah sebagai berikut:

1. Dinas Ketahanan Pangan Kabupaten Lampung Barat, hendaknya mempertimbangan perbaikan dan pembaharuan lingkungan kerja yang kondusif dan nyaman bagi pegawai.

2. Dinas Ketahanan Pangan Kabupaten Lampung Barat, hendaknya selalu dapat meningkatkan produktifitas kerja pegawainya dengan memanfaatkan lingkungan kerja yang sudah ada.

3. Kepala Dinas Ketahanan Pangan Kabupaten Lampung Barat, hendaknya memberikan rewand kepada pegawainya sesuai dengan kemampuan dan kualitas yang dimiliki sesuai dengan kinerjanya.

\section{DAFTAR PUSTAKA}

Algifari. 2013. Statistik Penelitian. Jakarta: Presshindo.

Anoraga, Panji. 2013. Lingkungan Fisik Kerja. Jakarta: Rajawali Perdana.

Bodnar, George H., dan William S. Hopwood. 2010. Pembinaan untuk Meningkatkan Kinerja Karyawan. Penerjemah Ramlan. Jakarta: PPM.

Ferdinand. 2008. Metode Penelitian Bisinis. Bandung: ANDI offset.

Kussriyanto. 2010. Administrasi Kepegawaian suatu Pengembangan. Jakarta: Rajawali.
Mangkunegara, Anwar P. 2008. Manajemen Sumber Daya Manusia Perusahaan. Bandung: PT. Remaja Rosdakarya.

Nitisemito, Alex S. 2009. Manajemen Sumber Daya Manusia. Jakarta: Penerbit Indonesia.

Ravianto, John. 2012. Produktivitas dan Pengukuran. Jakarta: Penerbit Lembaga Sarana Informasi Usaha dan Produktivitas.

Sedarmayanti. 2009. Sumber Daya Manusia dan Produktivitas Kerja. Bandung: Mandar Maju.

Siagian, Sondang P. 2012. Peranan Staf dan Manajemen. Jakarta: CV.Gunung Agung.

Sinungan, M. 2013. Produktivitas Apa dan Bagaimana. Jakarta: Bumi Aksara.

Suharsimi, Arikunto. 2010. Prosedur Penelitian, Edisi Kelima. Penerbit. Jakarta: Bineka Cipta.

Sugiyarso, G., dan F. Winarni. 2008. Manajemen Sumber Daya Manusia. Jilid 2. Jakarta: Salemba Empat.

Sugiyono. 2012. Metode Penelitian Kuantitatif dan Kualitatif dan $R \& D$. Bandung: CV. Alpha Beta.

Sutrisno, Edy. 2010. Manajemen Personalia dan Sumber Daya Manusia, Edisi 2. Jakarta: BPFE.UI.

Tarwaka, dkk. 2014. Produktivitas dan Manusia Indonesia. Jakarta: Ghalia Indonesia. 